\title{
Contribution of Technology to Insurance in Indonesia
}

\author{
Karin Amelia Safitri ${ }^{1 *}$ \\ ${ }^{1}$ Insurance Administration and Actuary, Vocational Education Program, \\ Universitas Indonesia \\ *Email: karinka1803@gmail.com
}

\begin{abstract}
In recent years, Indonesia has begun to develop its information and communications technology. Along with the development and spread of the use of information and communications technology in everyday life, the need for information, business world, and community responsibility has also increased, including insurance companies. Insurance companies act as a form of risk control by transferring the risk from one party to another. The growth of the insurance industry reflects the expanding need for protection both for health and assets owned. The growing awareness of insurance is inseparable from the influence of people's rising income and the development of digital technology. This paper investigates factors that affect the insurance variable related to the technology proxy in Indonesia from 2003 to 2015. Time-series data were analyzed using regression modeling with assumption-checking. Mobile user subscriptions, individual Internet users, Information and communications technology (ICT) goods, and ICT services are found to significantly and positively affect the insurance variable. The results indicate that insurance industry policy makers should start developing online premium policies and an online claim system.
\end{abstract}

Keywords: insurance, technology

\section{Introduction}

Information and communications technology (ICT) has become part of the world community and not least in Indonesia. ICT has had a positive impact by making work and home life more effective and efficient. As a developing country, Indonesia is still not advanced in the ICT mastery and development. Based on data from the United Nations Development Programme (UNDP) in 2013, Indonesia's technological achievement index is ranked 60th out of 72 countries. In recent years, however, Indonesia has begun to develop its ICT. Along with the development and dispersion of ICT in everyday life, the need for information in the business world and the community has also increased, including insurance companies. ICT makes better business, and businesses that fail to use this technology for their services will soon disappear. Currently, in Indonesia, many insurance companies have launched their digital services through their website and mobile applications. These mobile applications can be viewed and used to create reports onscreen. Insurance companies are the means and means used as collectors of funds, savings, and places of investment. The development of technology and communications in insurance companies in Indonesia Companies with consumers, accelerated processes and information, and help improve and improve insurance in the country. Research conducted by J. D. Power in 2016 showed that of the $74 \%$ of respondents who have insurance, only about $25 \%$ actually buy through the digital platform. Using the current ICT, customers are still searching for and using the products they want. The use of technology when choosing insurance products through a site or application is not always an effective way to explain very complex information. The presence of technology in insurance companies also provides benefits in the efficiency of operational costs and strategies to expand the introduction of insurance products among the community. According to Salatin (2014), the development of electronic sales causes insurance companies to become more product-oriented than customer-oriented. Waita and Nairobi (2014) found a positive impact of technological developments on the growth of microinsurance in Kenya. Because Indonesia is a developing country where the last few years the development of technology whose usefulness is seen in real life in everyday life, this is what makes the researchers stated that there is a significant influence on the existing insurance from Lin. Wen and Lin (2012) say that technology affects the cost efficient in the insurance industry that is only available in developed countries but not in developing countries.

This study aimed at investigating the factors affecting the insurance variable related to technology proxies in Indonesia by using time-series data from 2003 to 2015 . The four hypotheses tested are:

The relationship between the number of mobile users (per hundred people) as an technology index on insurance and financial services (\% of service exports) as an insurance industry index is positive and significant. the percentage of individual using Internet and insurance and financial services (\% of commercial service exports) is positive and significant.

the ICT good export and insurance and financial services (\% of commercial service exports) is positive and significant.

the ICT service export and insurance and financial services (\% of commercial service exports) is positive 
and significant.

and the percentage of Communication, computers etc. and insurance and financial services $(\%$ of commercial service exports) is positive and significant.

\section{Literature Review}

Forman and Gron (2011) found that by using information technology for product distribution, communications between insurance companies and customers were faster. Insurance agents have an important role in the insurance industry, and there are two types of relationships between insurance companies and their agents: agents that compete to represent several different insurers ("agents") and those that represent one company exclusively ("exclusive agents"). In general, the use of ICT in the insurance industry has improved the distribution of customer products and services based on the literature and cases studied in [9]. Other research on ICT from Odoyo and Nyangosi (2011) found increased financial transparency, higher productivity, brand and brand promotions, and increased sales volume in insurance companies using ICT. The implementation of ICT in India is more widely applied in private insurance companies than state insurance companies [10]. Bazini and Madini (2015) divided the benefits of using ICT in insurance companies into two groups: real and intangible. The real benefits of ICT implementation are improved timeliness of operational hours in insurance companies, organized and adequate information storage facilities, faster communication tools, and a reduction in the number of businesses put into in work. Intangible benefits include the influence of ICT to increase customer satisfaction and corporate image. ICT implementation in insurance companies has become vital in order to meet the need for faster operations, such as processing claims. Most insurance companies in Albania now see the need for insurance companies to incorporate ICT into their business objectives even though they face the challenge of formulating appropriate and strategic policies in positioning ICT to deliver effective and satisfying services to their customers. In addition, the need for professional involvement, consultants, and qualified practitioners in the insurance company to be responsible for managing ICT is a very important decision that executives and decision makers should consider as they strategically position ICT so that the perception of business competition becomes better and the level of utilization is maximized [11].

Yadollahi and Eslambolchi (2014) found that the emergence of e-trade has caused insurers to be more product- than customer-oriented. The authors found a significant effect of ICT on the insurance industry in Kenya, especially due to the growth of microinsurance (Masila, 2014). Another study related to the development of technology on insurance from Lin, Wen, and Lin (2012) suggested that ICT improves cost efficiency in developed countries more than in emerging economies. Sapa, Phunde, and Godbole (2015) conducted a comparative study between e-insurance and traditional insurance to see how e-insurance has progressed in interacting electronically with its customers and to identify any shortcomings [12]. Apampa (2010) found that most insurance companies in Nigeria have yet to align ICT with their business and organizational goals. Although most have adopted ICT for business functions, its role in insurance is yet to be fully understood. Thirteen insurance companies and two (2) insurance brokerage firms were surveyed. For most insurance executives and managers, ICT is very important and highly regarded in the organizational value chain [13]. Tamodharan and Ramesh (2010) found that the age groups of the respondents had significant differences from only print advertisement regarding awareness, interest, and purchase intention. Rural people below the age of 35 have an interest to digitally access insurance information. The education and income levels of the rural respondents did not influence awareness with respect to insurance advertising and information from print, visual, and web media. However, their occupation influenced only on getting interest from print media toward insurance. In the case of visual advertising, the occupation of respondents only had influence on purchase intention. Monthly income did not influence awareness of the service but did influence on raising interest and purchase intention with regard to insurance advertising. Web media attracted rural customers in terms of raising awareness and purchase intention, but did not generate interest toward insurance information or advertising [14]. Malit and Muendo (2017) found that ICT competency affects the performance of the insurance sector in Kenya to a great extent. Competency means that insurance sector employees have experience with various ICT platforms and are equipped with the right knowledge on information technology. The study recommended that insurance companies include a considerable amount of capital in their budget for ICT investment purposes [15].

\section{Methodology}

This study utilized secondary time-series data with a yearly sequence from 2000 until 2016. The percentages of mobile and Internet users are the proxies of technology variables. The dependent variable is the insurance penetration rate. Table 1 shows the definitions of variables used in this study. 
Table 1. Variable Definitions

\begin{tabular}{|c|c|c|c|c|c|}
\hline No. & Abbreviation & Variable & Measurement & Symbol & Unit \\
\hline 1 & INS & Insurance proxy & $\begin{array}{ll}\begin{array}{l}\text { Insurance } \\
\text { volume }\end{array} & \text { premium }\end{array}$ & $Y_{1 \mathrm{t}}$ & $\begin{array}{l}\text { Million } \\
\text { Rupiahs }\end{array}$ \\
\hline 2 & MUS & Mobile users & $\begin{array}{l}\text { Number of mobile user } \\
\text { subscriptions }\end{array}$ & $Y_{2 \mathrm{t}}$ & $\begin{array}{l}\text { Million } \\
\text { Rupiahs }\end{array}$ \\
\hline 3 & IDI & Internet & $\begin{array}{l}\text { Percentage of individual } \\
\text { using Internet }\end{array}$ & $Y_{\mathrm{at}}$ & Percent \\
\hline 4 & IGE & ICT goods & $\begin{array}{l}\text { Percentage of ICT goods } \\
\text { and total exports }\end{array}$ & $x_{1 t}$ & Percent \\
\hline 5 & ISE & ICT service & $\begin{array}{l}\text { Percentage of ICT goods } \\
\text { and total exports }\end{array}$ & $X_{2 t}$ & Percent \\
\hline 6 & CCE & $\begin{array}{l}\text { Communication, } \\
\text { computers, etc. }\end{array}$ & $\begin{array}{l}\text { Percentage } \\
\text { communications, of } \\
\text { computer, } \\
\text { information }\end{array}$ & $X_{a t}$ & $\begin{array}{l}\text { Million } \\
\text { Rupiahs }\end{array}$ \\
\hline
\end{tabular}

The methodology has the following steps:

1. Form the hypotheses for testing

a. Hypothesis I: The number of mobile users (per hundred people) as an technology index on insurance and financial services (\% of service exports) as an insurance industry index is positive and significant.

b. Hypothesis II: The percentage of individual using Internet and insurance and financial services (\% of commercial service exports) is positive and significant.

c. Hypothesis III: The ICT good export and insurance and financial services (\% of commercial service exports) is positive and significant.

d. Hypothesis IV: The ICT service export and insurance and financial services (\% of commercial service exports) is positive and significant.

e. Hypothesis V: The percentage of Communication, computers etc. and insurance and financial services (\% of commercial service exports) is positive and significant.

2. Build the regression model.

3. Explore the trend and descriptive statistics of each variable, including mean and variance.

4. Apply the regression model. The larger the R-squared, the more the dependent variables can be explained by the variation of the independent variable.

5. Interpret the result.

6. Conclude the study.

\subsection{Time-series regression}

The common form of multiple linear regression model with $p$ independent variables is expressed as Equation (1) (Kutner, Nachtsheim, and Neter, 2004):

$$
Y_{i}=\beta_{0}+\beta_{1} X_{i 1}+\beta_{2} X_{i 2}+\cdots+\beta_{p-1} X_{i, p-1}+\varepsilon_{i} \ldots \text { (1) }
$$

where $Y_{\hat{i}}$ is the independent variable for the $i$-th observation for $i=1,2, \ldots, n$, $\beta_{0,} \beta_{1, \ldots} \beta_{p-1}$ are the parameters, $X_{\mathrm{i} 1}, X_{\mathrm{i} 2, \ldots,}, X_{\mathrm{i}, p-1}$ are dependent variables, and $\varepsilon_{\mathrm{i}}$ is the residual (error) for the observed $i$-th, which is assumed to be normally distributed independently and identical with the average 0 (zero) and variance $\sigma^{2}$.

The linear multiple regression (or "ordinary least squares") method (OLS) was used in this study to estimate the model

parameters.

The OLS method aims to minimize the sum of squared error. Based on Equation (2), the OLS estimators obtained for $\beta$ are as follows (Kutner, Nachtsheim, and Neter, 2004):

$$
\hat{\beta}=\left(X^{T} X\right)^{-1} X^{T} Y \ldots(2)
$$

\section{Discussion}

Along with the increase in total insurance premiums, other insurance performance indicators, such as insurance density (insurance premium per capita) and insurance penetration (ratio of total insurance premiums to GCP), also increased. In the period 2003-2015, insurance density experienced the highest increase in 2013 of 77 million, which then decreased in 2014 to 60 million. That is, during that period, the amount of per capita population expenditure to pay insurance premiums increased by approximately $21.43 \%$ on average per year. 
Increased public expenditures are at once an indication of an increase in public demand for insurance services. This is reflected in the penetration rate of the insurance industry which increased from $1.4 \%$ in 2003 to $2.35 \%$ in 2015 (Figure 1). Although the improvement of both insurance performance indicators has not shown a sharp increase, there is still an increasing demand trend, indicating that literacy or public awareness about insurance has developed.

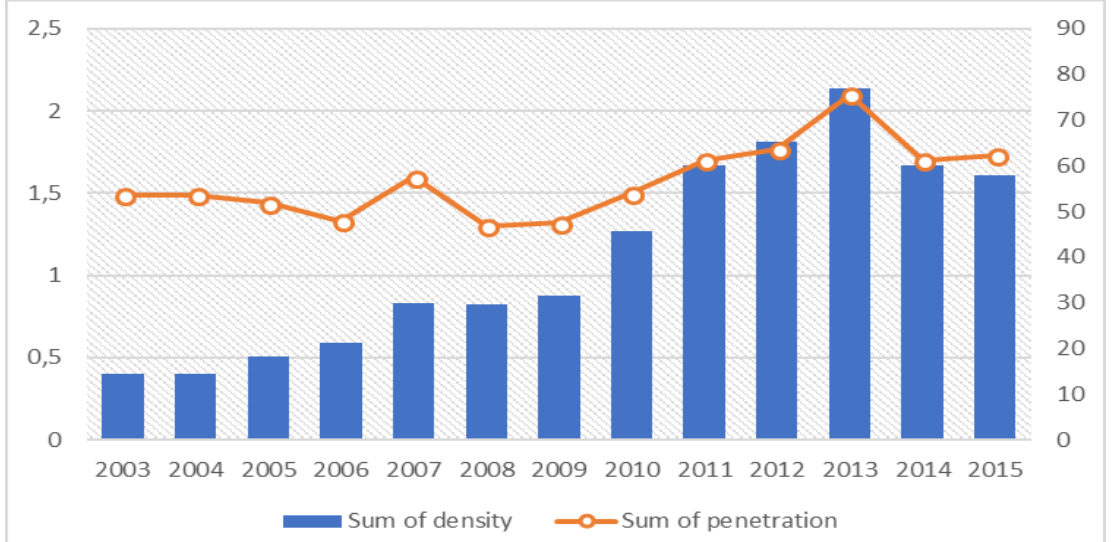

Figure 1. Insurance density (left axis) and penetration percentage (right axis) in Indonesia 2003-2015

The growing awareness of insurance is inseparable from income; however, income does not affect technological development. All levels of society can enjoy information technology very quickly and at a cost that is not too expensive. Rapid technological developments also have a role in increasing the insurance density in Indonesia. Figure 2 indicates that insurance proxy includes exported freight insurance and other insurance losses, insurance broker services, and life insurance. For transactions in the insurance industry recorded the net value of the premium minus claims.

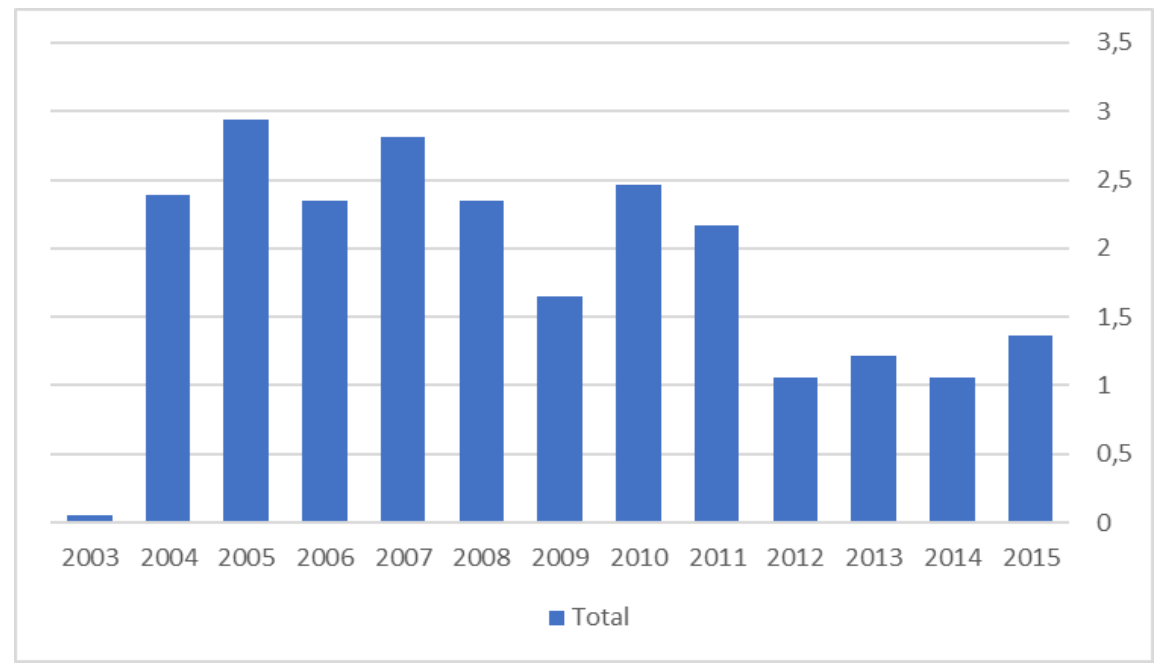

Figure 2. Insurance and financial services as a percentage of service exports in Indonesia 2003-2015

The insurance and financial services industry is very dynamic. In 2013, it was down almost to zero because the penetration of insurance and financial services did not reach households.

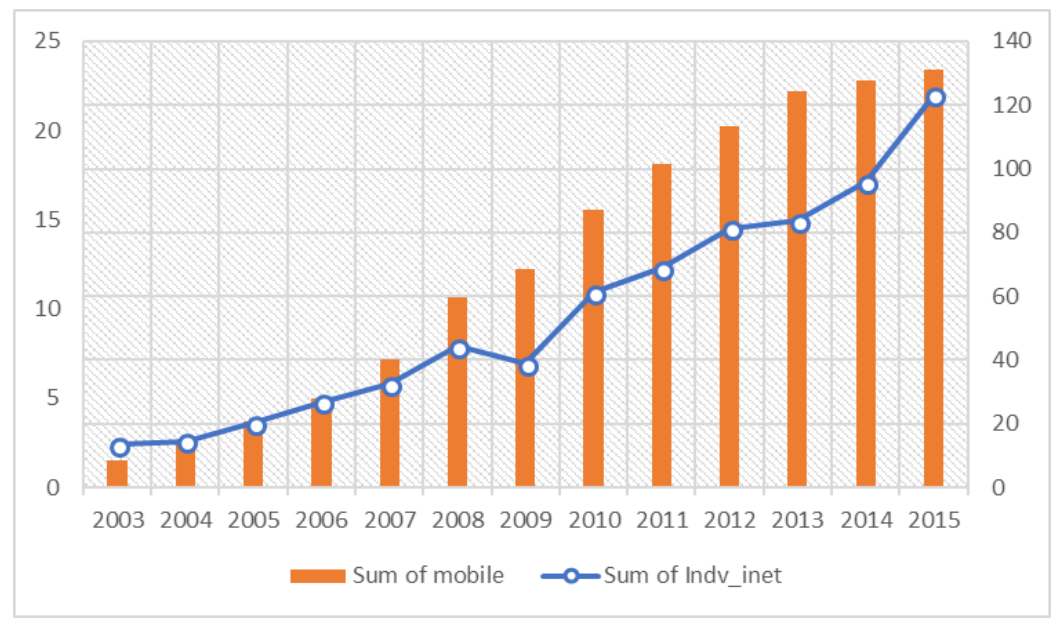


Figure 3. Percentage of Internet users and number of mobile device users in Indonesia 2003-2015

Figure 3 shows that the number of mobile phone subscriptions and individual Internet users is increasing annually. Mobile phone subscription proxy is a customer using a cell phone service. Some indicators used to measure mobile phone subscriptions are the number of post-paid mobile phone subscriptions and active prepay accounts over the last 3 months. Variable mobile phone subscriptions tend to have an upward trend annually. Advancements in mobile technology are making them easier to use. Mobile phone rates tend to be inexpensive in Indonesia, which makes the service accessible to all citizens. The variable of Internet users from the Internet (from any location) in the last 3 months. The Internet can be accessed through a computer, mobile phone, personal digital assistant, games machine, digital TV, etc. The percentage of Internet users in Indonesia is also increasing annually, and there are many choices of packages with various price plans.

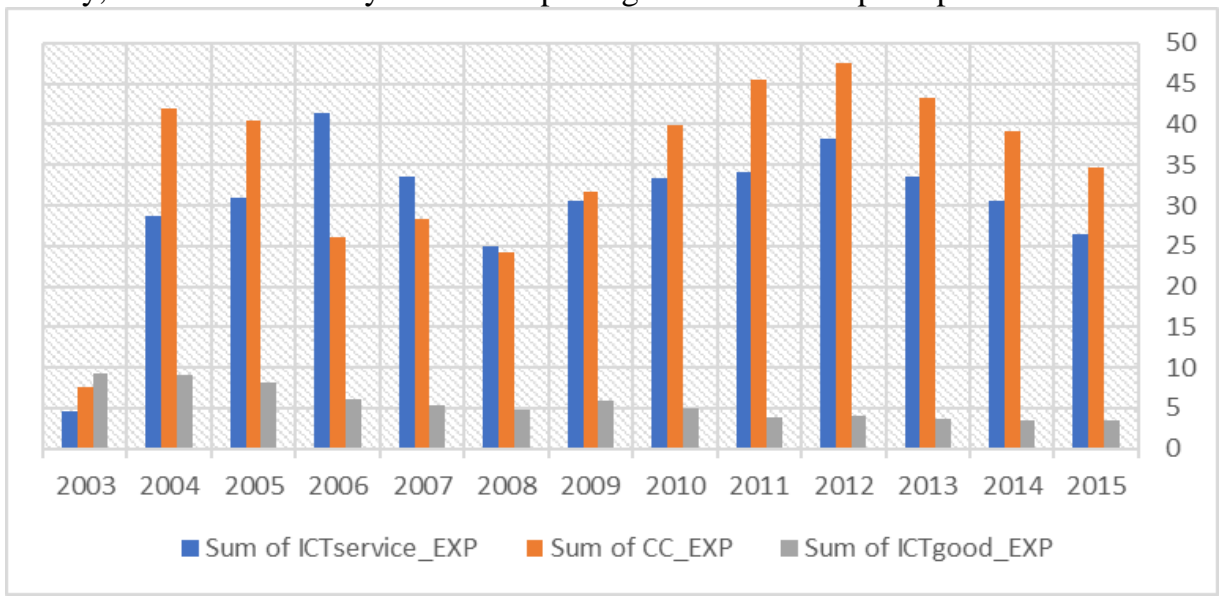

Figure 4. Percentage of ICT service, computer and communication, and ICT goods exports in Indonesia 2003-2015

Figure 4 shows that a fixed broadband subscription means subscriptions will remain accessible to the public Internet with a superfast keycode that exceeds $256 \mathrm{~kb}$. Included in fixed broadband subscriptions are cable modems, digital subscriber lines, other cable broadband subscriptions, broadband satellites, and wireless broadband. This fixed broadband subscription is measured using the amount and frequency of payments. ICT has revolutionized how people communicate, learn, do business, and seek healthcare and offers diverse opportunities for economic improvement, better social services, the creation of distance education, and improved health of a country. Data covering Internet access and quality, frequency of use, and affordability of technology that can be used by the community can also be used by the government to formulate policies related to state development. Not all countries provide support to their citizens to enjoy the development of technology as some countries shut themselves out of the technology and the development of the outside world. As a result, they do not know how ICT can be used in schools, offices, businesses, research, and government. Tables 2 and 3 report the descriptive statistics of the variables and the results of the correlation test, respectively.

Table 2. Descriptive Statistics of Variables

\begin{tabular}{l|rrrrrrrr}
\hline Variable & \multicolumn{1}{|c}{ INS } & IDI & IGE & CCE & ISE & MUS & & \\
\hline Mean & 1.834 & 9.673 & 5.547 & 34.634 & 30.040 & 71.051 & 40.415 & 1.574 \\
Std. Error & 0.234 & 1.710 & 0.578 & 3.065 & 2.440 & 12.755 & 5.973 & 0.062 \\
Median & 2.166 & 7.917 & 4.983 & 39.226 & 30.938 & 68.386 & 31.6 & 1.5 \\
Std. & 0.843 & 6.168 & 2.085 & 11.051 & 8.798 & 45.991 & 21.536 & 0.225 \\
Deviation & & & & & & & & \\
Variance & 0.712 & 38.044 & 4.347 & 122.131 & 77.411 & 2115.189 & 463.819 & 0.050 \\
Kurtosis & -0.164 & -0.598 & -0.499 & 1.747 & 6.103 & -1.684 & -1.446 & 1.040 \\
Skewness & -0.649 & 0.583 & 0.898 & -1.245 & -2.070 & -0.017 & 0.283 & 0.899 \\
Range & 2.887 & 19.589 & 5.840 & 40.103 & 36.682 & 122.906 & 62.5 & 0.8 \\
\hline
\end{tabular}

Table 3. Correlation Among Variables

\begin{tabular}{lrrrrrr}
\hline & \multicolumn{1}{c}{ INS } & \multicolumn{1}{c}{ IDI } & \multicolumn{1}{c}{ IGE } & CCE & ISE & MUS \\
\hline INS & 1 & & & & & \\
IDI & -0.346 & 1 & & & & \\
IGE & 0.076 & -0.858 & 1 & & & \\
CCE & 0.268 & 0.466 & -0.447 & 1 & & \\
ISE & 0.541 & 0.245 & -0.499 & 0.696 & 1 &
\end{tabular}




\begin{tabular}{|c|c|c|}
\hline MUS & & \\
\hline
\end{tabular}

The correlation test found that mobile phone subscriber variables are negatively correlated with ICT in the form of goods. Variables of individuals using the Internet and ICT in the form of goods have strong and negative correlation coefficients. A strong and positive relationship is seen between the variables of insurance and ICTs in the form of services between cell phone subscriptions and individuals using the Internet. Data were processed in Microsoft Excel using the following regression model:

$$
\mathrm{INS}=7.16+0.0932 \mathrm{IDI}+0.751 \mathrm{IGE}+0.0797 \mathrm{CCE}+0.0230 \mathrm{ISE}+0.0580 \mathrm{MUS}
$$

Yadollahi and Eslambolchi (2014) revealed that subscriptions of mobile users can increase the productivity of the insurance industry in selected countries. The coefficient of the subscriptions of mobile users also satisfies the hypothesis of positively affecting the insurance and financial service variable and is statistically significant. The R-squared value is $81.6 \%$. This shows that the independent variables are able to explain $81.6 \%$ of the variability of the dependent variable. Under the insurance and financial services model, the coefficient of the individual using Internet has a positive effect and is significant at the 5\% level, therefore confirming Hypothesis II. The coefficient of ICT goods is also statistically significant at the 5\% level and has a positive effect on insurance and financial services demand as hypothesized because of referring to the study from Lin, Wen, and Lin (2012). ICT services are hypothesized to increase the demand for insurance and financial services, and the empirical result showed the same, with a positive effect on the insurance demand. This fact leads to the conclusion that it fit the theory refer to Yadollahi and Eslambolchi (2014). Under the insurance model, the computer and communication has a positive and significant effect on insurance at $\alpha=5 \%$.

\section{Conclusion}

The growing awareness of insurance is inseparable from the influence of the increase in people's income and the development of digital technology. Mobile user subscriptions, individual Internet users, ICT goods, and ICT services all affect the insurance variable. This could be a consideration for policy makers in the insurance industry to start developing online premium policy and claims systems.

\section{References}

Apampa, O. R. (2010). Evaluation of ICT Penetration in Selected Insurance Companies : The Lagos Experience. J. Emerg. Trends Comput. Inf. Sci., 1(1), 24-30.

Bazini, E., \& Madani, F. (2015) ICT Application in the Insurance Industry: Its Impact in Customer Relationship Management. Acad. J. Interdiscip. Stud., 4(3), 307-311.

Forman, C., \& Gron, A. (2011). Vertical integration and information technology investment in the insurance industry. J. Law, Econ. Organ., 27(1), 180-218.

Horizons, E., Thamodaran, V., \& Ramesh, M. (2010). Effectiveness of information communication technology in rural insurance. Business and Economic Horizons (BEH), 2(1232-2016-101137), 98-105.

Lin, H. J., Wen, M. M., \& Lin, W. T. (2012) The relationships between information technology, e-commerce, and e-finance in the financial institutions: Evidence from the insurance industry, Lect. Notes Comput. Sci. (including Subser. Lect. Notes Artif. Intell. Lect. Notes Bioinformatics), vol. 7197 LNAI, no. PART 2, pp. 194206.

Malit, A., \& Muendo, D. (2017). "The effect of information communication technology strategy implementation on organizational performance of insurance sector in Kenya. Strategic Journal of Business \& Change Management, 4(2).

Masila, C. W. (2014). The Relationship between advancement in technology, competition subsidies and the growth of micro insurance in Kenya. Master of Business Admistration degrees university of Nairobi, 1-64.

Odoyo, F. S., \& Nyangosi, R. (2011) E-Insurance : an empirical study of perceived benefits. Int. J. Bus. Soc. Sci., 2(21), 166-172.

Salatin, P., Yadollahi, F., \& Eslamboichi, S. (2014). The Effect of ICT on insurance industry in selected countries. Res. J. Econ. Business ICT, 9(1).

S. Sapa, S., Phunde, S. B., \& Godbole, M. R. (20014). Impacts of ICT Application on the Insurance Sector (EInsurance). IBMRD's J. Manag. Res., 3(1), 311-320. 